\title{
Blood pressure in children, adolescents and young adults with Type 1 (insulin-dependent) diabetes
}

\author{
A.C.Tarn and P.L. Drury \\ Departments of Medicine, Diabetes and Endocrinology, St. Bartholomew's Hospital, West Smithfield, London, UK
}

Summary. Blood pressure has been measured by a single observer using a standardised technique in 163 Type 1 (insulindependent) diabetic patients aged 4 to 32 years, 232 of their non-diabetic siblings in the same age range and in 292 of their natural parents. Results for each sex were examined separately by analysis of variance. Systolic pressures were not significantly different overall nor in any single 4-year age band. In contrast, phase IV diastolic pressure was slightly but significantly higher in the diabetic males than in their sibling group overall (increment $=+2.8 \mathrm{mmHg} ; p<0.03$ ), a difference also shown individually within the 16-20 year age band ( 81.3 versus $76.5 \mathrm{mmHg}, p<0.025$ ). There were no significant differences in diastolic pressure between the female groups, and no effect of duration of diabetes on blood pressure was shown in either sex. Eighteen of 97 male diabetic patients (19\%) had mean blood pressures above the 90 th centile for age, derived from the sibling data, compared with 12 of 137 siblings $(9 \%$, $p=0.05$ ). The higher blood pressures among the diabetic males could not be explained solely by early nephropathy; familial factors appeared to be important in the determination of elevated blood pressure in this group as well as in the siblings. Alone, these small differences in blood pressure are unlikely to make a major contribution to the incidence of diabetic vascular disease, but the isolated increase in diastolic pressure may indicate altered vascular regulation in Type 1 diabetes.

Key words: Blood pressure, Type 1 (insulin-dependent) diabetes, nephropathy, albumin excretion, hereditary factors.
In adults with Type 1 (insulin-dependent) diabetes, as in the general population, hypertension is a major risk factor for the development of cardiovascular and cerebrovascular disease [1]. There is also some evidence that hypertension may accelerate the progression of diabetic retinopathy [2].

Most patients develop Type 1 diabetes during childhood or adolescence, but the data on blood pressure (BP) in children, adolescents and young adults with Type 1 diabetes are limited and conflicting. Moss [3] showed raised systolic pressures (SBP) after the age of 13 in both boys and girls, whilst Kaas-Ibsen et al. [4] showed similar SBP but lower diastolic pressures (DBP) in diabetic girls. A recent study from Edinburgh showed raised DBP amongst those diabetic patients with retinopathy and microalbuminuria [5], while Cruickshanks et al. [6] reported higher SBP and DBP in 149 diabetic adolescents aged 9-16 years compared with 45 unaffected siblings.

Increased BP is now accepted as a feature of diabetic nephropathy, even from its early stages [7-11]. Whilst clinical nephropathy is unusual in patients who have been diabetic for less than ten years [12], an earlier stage characterised by "microalbuminuria" (urinary albumin excretion rates of $30-200 \mu \mathrm{g} / \mathrm{min}$ ) may occur in patients with a shorter duration of diabetes. Small increases in the BP of some children and adolescents might therefore be expected, especially if their diabetes developed in early childhood.
We have therefore compared the BP of a cohort of Type 1 diabetic children, adolescents and young adults with those of their non-diabetic siblings. Our aim was primarily to determine if there were any systematic differences in blood pressure between the groups or if there was any evidence of a sub-group of diabetic patients with relatively increased blood pressure. A secondary purpose was to examine possible aetiological factors associated with this "relative hypertension", if present.

\section{Subjects and methods}

\section{Subjects}

The group studied was one of 160 families previously enrolled in the Barts-Windsor prospective family study of diabetes. Since 1978, 209 families have participated; 49 have subsequently moved away or declined further follow-up. Families were ascertained through clinic registers and general practitioners in the area of East Berkshire, North Surrey and South Buckinghamshire, and were selected for the presence of a Type 1 (insulin-dependent) diabetic child or young adult and at least one non-diabetic sibling [13]. All families had given informed consent to inclusion in the study.

The study began in 1978 but BP was not recorded until the present investigation, which took place between August 1983 and December 1984. Only subjects then aged between 4 and 32 years were included; in some age groups (below 8 years and above 28 years) too few were available for detailed statistical analysis.

Blood pressures were recorded in all but 1 eligible proband (who declined to participate) and in all family members still resident within 
the study area. These comprised 163 Type 1 diabetic subjects, 232 non-diabetic siblings and 292 parents (155 mothers, 137 fathers); details are shown in Table 1 . Both the diabetic and sibling groups show a male excess previously noted (diabetic patients $60 \%$ male, $40 \%$ female; siblings 59\% male, $41 \%$ female) [14].

\section{Blood pressure measurements}

All BP measurements were made in the subjects' homes by a single non-uniformed observer [15]. No strenuous exercise was undertaken in the $2 \mathrm{~h}$ preceding the measurements. Following venesection for other indications, the subjects remained seated for $5 \mathrm{~min}$ before the recordings were made. The families were accustomed to regular visits and venesection, which applied to diabetic children, siblings and parents alike. Approximately $90 \%$ of readings took place between 16.00 and 21.00 hours.

Pressures were recorded in the right arm with a single Hawksley random zero sphygmomanometer using the appropriate sized cuff (child, adult or large arm - Hawksley and Sons, Lancing, Sussex), the arm being in a supported semi-dependent position [16, 17]. After an initial inflation and deflation of the cuff, three readings of Korotkoff phases I, IV and V were made at 1-min intervals, each to the nearest $2 \mathrm{mmHg}$; the mean of these three readings was used for analysis. The calibration of the machine was checked every $2-3$ months.

\section{Laboratory methods}

A random mid-stream urine sample was collected at the time of the BP measurement in all but 5 subjects, and analysed for albumin concentration using a double antibody radioimmunoassay modified from the method of Keen and Chlouverakis [18]. Sensitivity was $2 \mathrm{mg} / 1$, intra-assay variation was $5.5 \%$ and inter-assay variation $8.3 \%$. Twentyfour hour urine collections were made on 22 of the 27 Type 1 diabetic patients with "relative hypertension", as defined below.

Parenthood was checked as being compatible with the HLA tissue typing available for the entire cohort.

\section{Statistical analysis}

Neither SBP nor DBP showed any significant deviation from a normal distribution. Pressures from males and females were analysed separately; data on both phases IV and V DBP are presented, although phase IV is preferred for work in children [19]. Differences in $\mathrm{BP}(\triangle \mathrm{BP})$ are expressed as (BP for diabetic group) - (BP for sibling group) throughout.

Two-way analysis of variance, by age band and diabetic status, was carried out in 2- and 4-year age bands, using only the ages 8-28 years, where adequate numbers were available. The significance of differences within individual age bands was then obtained by calculating the confidence intervals for the difference in means between the diabetic and sibling groups.
In addition, overall DBPs, which changed little or not at all with age, were compared between diabetic and sibling groups by one-way analysis of variance.

To allow calculation of centiles for each age, polynomial regression equations of cubic form for SBP, DBP and mean BP were calculated for each sex from the non-diabetic sibling data in the manner of Hamilton et al. [20]. For mean BP (diastolic $+1 / 3$ pulse pressure), these were used to derive the 10th, 50th and 90th centiles at each age.

These equations are, for female mean BP:

$49.17+5.422 \times$ age $-0.2463 \times$ age $^{2}+0.003692 \times$ age $^{3} \quad\left(r^{2}=0.12\right)$ and for male mean BP:

$$
52.92+4.262 \times \text { age }-0.1580 \times \text { age }^{2}+0.002367 \times \operatorname{age}^{3}\left(r^{2}=0.32\right)
$$

\section{Definition of "relative hypertension"}

Subjects were, for the purposes of this study, defined as having "relative hypertension" if their mean BP exceeded the 90th centile for age and sex. For example, at age 20 this corresponds to a mean BP of $105 \mathrm{mmHg}$ for males and $101 \mathrm{mmHg}$ for females.

\section{Results}

The Type 1 diabetic and non-diabetic sibling groups were comparable for age and body mass index (Table 1).

Numbers in each age/sex group and exact BPs, with statistical significance of differences where present, are shown in Table 2. The pattern of change of BP with age is shown in Figure 1.

\section{Systolic blood pressure}

By two-way analysis of variance, irrespective of whether 2-year or 4-year age bands were used, there was no overall significant effect of diabetic status on SBP for either females or males. Using the 4-year bands, the differences $(\triangle \mathrm{BP})$ were $-0.8 \mathrm{mmHg}$ for females and $-0.1 \mathrm{mmHg}$ for males $(p=\mathrm{NS})$.

There was evidence of a significant increase in SBP with age in both sexes $(p<0.025$ for females; $p<0.001$ for males).

Within individual 4-year age bands, there were also no significant differences in SBP between the diabetic and sibling groups for either sex (Table 2).

Table 1. Characteristics of subjects studies overall and by sex

\begin{tabular}{|c|c|c|c|c|c|c|}
\hline & \multicolumn{2}{|l|}{ All } & \multicolumn{2}{|l|}{ Males } & \multicolumn{2}{|l|}{ Females } \\
\hline & $\begin{array}{l}\text { Type } 1 \\
\text { diabetic } \\
\text { patients }\end{array}$ & Siblings & $\begin{array}{l}\text { Type } 1 \\
\text { diabetic } \\
\text { patients }\end{array}$ & Siblings & $\begin{array}{l}\text { Type } 1 \\
\text { diabetic } \\
\text { patients }\end{array}$ & Siblings \\
\hline Number studied & 163 & 232 & 97 & 137 & 66 & 95 \\
\hline Mean age (years) & $17.5 \pm 5.6$ & $17.6 \pm 5.6$ & $17.9 \pm 5.7$ & $18.1 \pm 5.6$ & $16.9 \pm 5.4$ & $17.0 \pm 5.6$ \\
\hline Age range (years) & $4.8-30.7$ & $4.8-31.5$ & $5.4-30.1$ & $6.1-31.2$ & $4.8-30.7$ & $4.8-31.5$ \\
\hline Mean weight (kg) & - & - & $56.7 \pm 16.0$ & $60.8 \pm 17.2$ & $53.1 \pm 14.1$ & $51.8 \pm 14.6$ \\
\hline Mean height (m) & - & - & $1.64 \pm 0.19$ & $1.69 \pm 0.17$ & $1.56 \pm 0.16$ & $1.57 \pm 0.15$ \\
\hline Body mass index $\left(\mathrm{kg} / \mathrm{m}^{2}\right)$ & - & - & $20.4 \pm 2.4$ & $20.9 \pm 3.6$ & $21.4 \pm 3.0$ & $20.5 \pm 3.8$ \\
\hline Duration of diabetes (years) & - & - & $8.1 \pm 4.8$ & - & $8.3 \pm 5.4$ & - \\
\hline Range of duration (years) & - & - & $0.6-23.2$ & - & $0.5-25.0$ & - \\
\hline
\end{tabular}

Results are mean $\pm \mathrm{SD}$, except where ranges are shown 

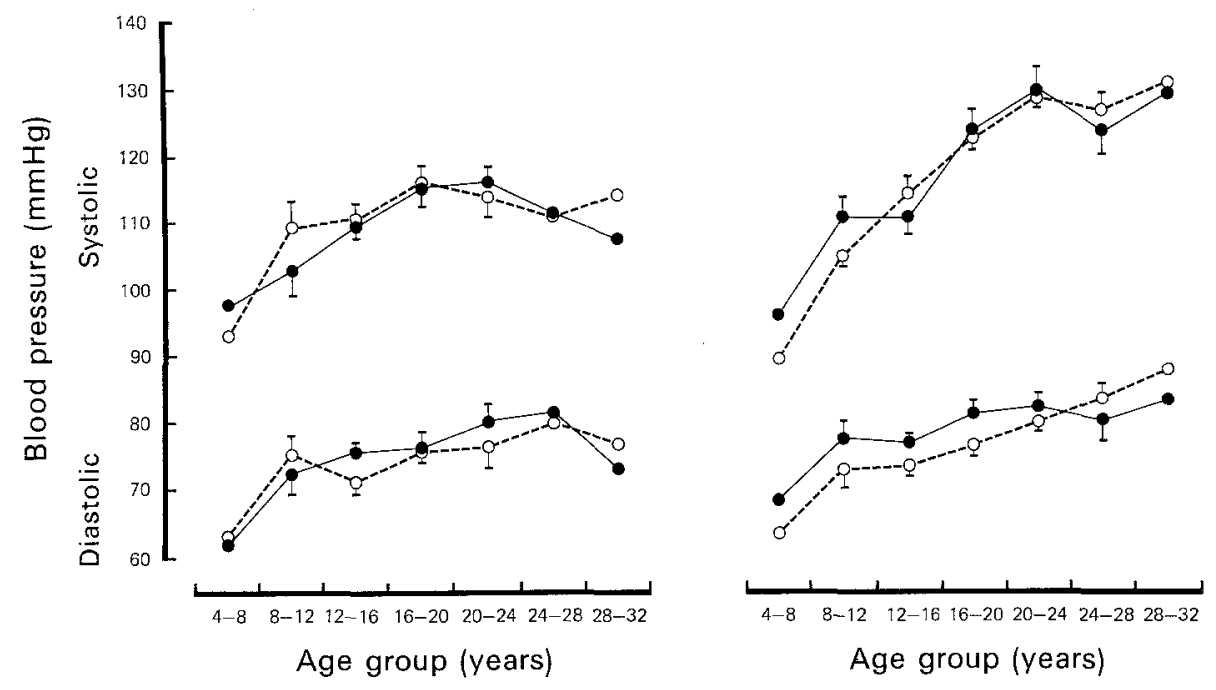

Fig.1. Systolic and phase IV diastolic blood pressures in Type 1 (insulin-dependent) diabetic patients $(\longrightarrow)$ ) and non-diabetic siblings $(\mathrm{O}-\mathrm{O})$ for each age band. $\mathrm{Re}$ sults for females are in left-hand panel; for males in right-hand panel. Results are mean \pm SEM, except when $n<8$, where the mean only is shown. Exact figures and statistical significance of differences are shown in Table 2

Table 2. Systolic and diastolic blood pressures by age and sex in Type 1 diabetic and non-diabetic sibling groups

\begin{tabular}{|c|c|c|c|c|c|c|c|c|}
\hline \multirow{2}{*}{$\begin{array}{l}\text { Age band } \\
\text { (years) } \\
\text { and group }\end{array}$} & \multicolumn{4}{|l|}{ Females } & \multicolumn{4}{|l|}{ Males } \\
\hline & Number & Systolic BP & Phase IV & Phase V & Number & Systolic BP & Phase IV & Phase V \\
\hline $\begin{array}{l}\text { 4- } 8 \text { Siblings } \\
\text { Diabetic patients }\end{array}$ & $\begin{array}{l}7 \\
3\end{array}$ & $\begin{array}{l}93.2 \\
97.5\end{array}$ & $\begin{array}{l}63.0 \\
61.8\end{array}$ & $\begin{array}{l}61.5 \\
61.8\end{array}$ & $\begin{array}{l}2 \\
4\end{array}$ & $\begin{array}{l}89.7 \\
96.5\end{array}$ & $\begin{array}{l}63.4 \\
68.2\end{array}$ & $\begin{array}{l}63.4 \\
65.7\end{array}$ \\
\hline $\begin{array}{l}\text { 8-12 } \\
\text { Siblings } \\
\text { Diabetic patients }\end{array}$ & $\begin{array}{l}10 \\
10\end{array}$ & $\begin{array}{l}109.4 \pm 12.7 \\
102.9 \pm 12.3\end{array}$ & $\begin{array}{l}75.1 \pm 9.6 \\
72.4 \pm 10.3\end{array}$ & $\begin{array}{l}72.1 \pm 8.9 \\
70.4 \pm 10.7\end{array}$ & $\begin{array}{r}20 \\
9\end{array}$ & $\begin{array}{l}105.3 \pm 7.9 \\
111.1 \pm 8.5\end{array}$ & $\begin{array}{l}73.0 \pm 6.9 \\
77.6 \pm 7.9\end{array}$ & $\begin{array}{l}70.5 \pm 7.1 \\
76.0 \pm 7.6\end{array}$ \\
\hline $\begin{aligned} & \text { 16-20 } \text { Siblings } \\
& \text { Diabetic patients }\end{aligned}$ & $\begin{array}{l}32 \\
14\end{array}$ & $\begin{array}{l}116.2 \pm 14.2 \\
115.8 \pm 12.4\end{array}$ & $\begin{array}{l}75.6 \pm 9.7 \\
76.0 \pm 9.4\end{array}$ & $\begin{array}{l}74.5 \pm 9.5 \\
74.2 \pm 8.2\end{array}$ & $\begin{array}{l}32 \\
27\end{array}$ & $\begin{array}{l}123.1 \pm 13.7 \\
124.2 \pm 12.8\end{array}$ & $\begin{array}{l}76.5 \pm 9.7 \\
81.3 \pm 9.2 \\
p<0.025\end{array}$ & $\begin{array}{l}73.5 \pm 10.6 \\
78.0 \pm 10.2\end{array}$ \\
\hline $\begin{array}{l}\text { 20-24 Siblings } \\
\text { Diabetic patients }\end{array}$ & $\begin{array}{l}17 \\
18\end{array}$ & $\begin{array}{l}114.1 \pm 12.5 \\
116.3 \pm 8.9\end{array}$ & $\begin{array}{l}76.4 \pm 12.6 \\
80.2 \pm 11.2\end{array}$ & $\begin{array}{l}74.5 \pm 12.2 \\
78.0 \pm 11.1\end{array}$ & $\begin{array}{l}31 \\
19\end{array}$ & $\begin{array}{l}128.6 \pm 9.7 \\
129.6 \pm 15.8\end{array}$ & $\begin{array}{l}79.9 \pm 8.6 \\
81.9 \pm 9.8\end{array}$ & $\begin{array}{l}77.0 \pm 9.7 \\
78.8 \pm 10.6\end{array}$ \\
\hline $\begin{array}{l}\text { 28-32 Siblings } \\
\text { Diabetic patients }\end{array}$ & $\begin{array}{l}4 \\
1\end{array}$ & $\begin{array}{l}114.2 \\
107.3\end{array}$ & $\begin{array}{l}76.7 \\
72.7\end{array}$ & $\begin{array}{l}75.3 \\
70.0\end{array}$ & $\begin{array}{l}6 \\
4\end{array}$ & $\begin{array}{l}130.5 \\
129.0\end{array}$ & $\begin{array}{l}87.8 \\
82.8\end{array}$ & $\begin{array}{l}84.1 \\
80.3\end{array}$ \\
\hline
\end{tabular}

Results are mean \pm SD; SDs are omitted where $n<8$ subjects. Statistical significance is by analysis of variance; where not shown, differences are not significant

\section{Diastolic blood pressure}

Males. Using two-way analysis of variance, phase IV DBP was higher in the male diabetic group than in the male sibling group, whether analysed in 2-year or 4-year age bands (2-year bands: $\Delta \mathrm{BP}=2.8 \mathrm{mmHg}, p<0.025$; 4-year bands: $\triangle \mathrm{BP}=2.7 \mathrm{mmHg}, p<0.03$ ). Results for phase V DBP showed the same trend but did not reach statistical significance $(\triangle \mathrm{BP}=2.5 \mathrm{mmHg}$ for 2-year or 4-year bands, $p<0.08$ for both).

The difference in phase IV DBP was significant individually within the $16-20$ year age band ( 81.3 versus $76.5 \mathrm{mmHg}, p<0.025)$, but not in any other band (Table 2).

Both phases IV and V DBP showed a significant rise with age $(p<0.01)$ over the range $8-28$ years.
Females. There were no significant differences in phase IV or phase V DBP between the diabetic and sibling groups whether analysed in 2- or 4-year age bands. Phase IV $\triangle \mathrm{BPs}$ were $1.8 \mathrm{mmHg}$ for 2-year and $1.9 \mathrm{mmHg}$ for 4 -year bands $(p>0.1)$, and phase V BPs 1.7 and $1.7 \mathrm{mmHg}$ respectively $(p>0.1)$.

There was no significant difference in DBP between diabetic and sibling groups for individual 4-year age bands.

Neither phase IV nor phase V DBP showed a significant change with age over the range $8-28$ years $(p>$ $0.05)$.

There was no evidence of any effect of duration of diabetes on SBP or DBP. 


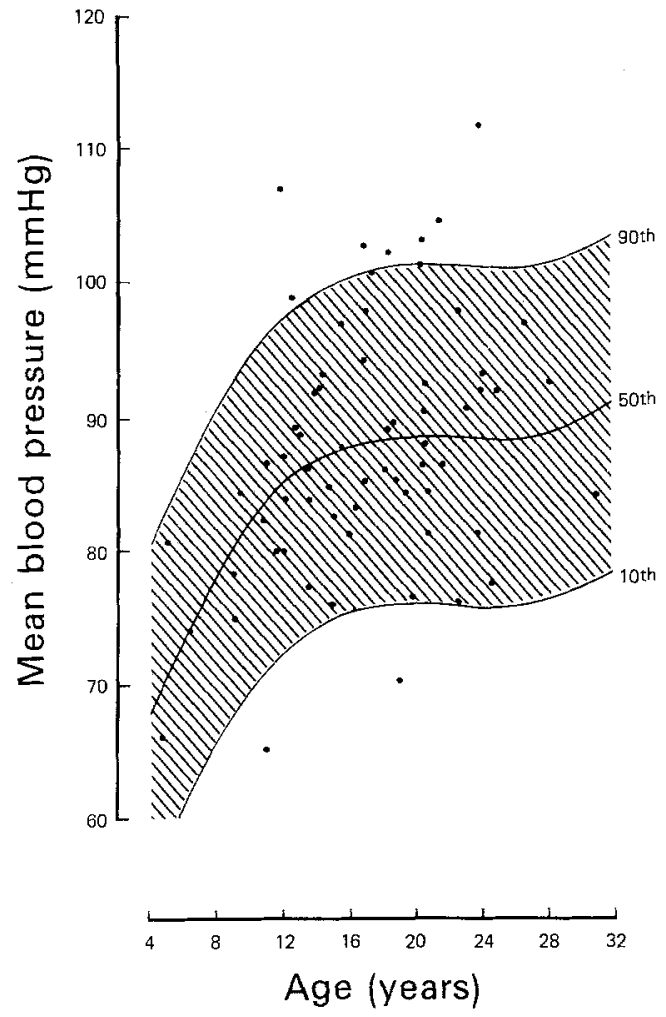

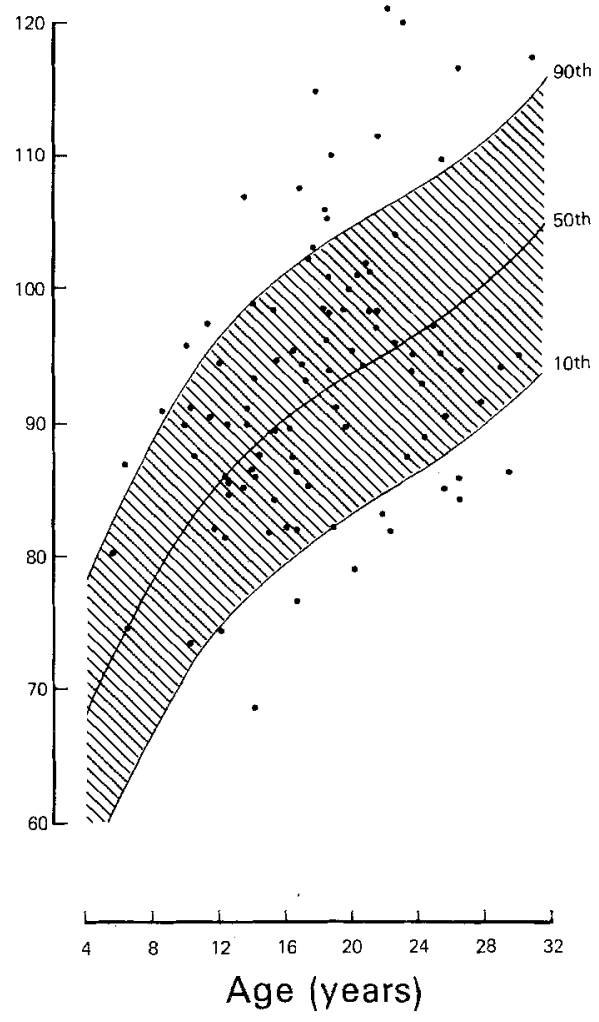

Fig.2. Individual mean blood pressures (diastolic $\pm 1 / 3$ pulse pressure) for Type 1 diabetic patients (O) shown with the 10th, 50th and 90th centiles of mean blood pressure calculated from the regression equations for the non-diabetic siblings. Results for females are shown in the left-hand panel; for males in the right-hand panel

\section{Individual mean blood pressures}

Mean BPs for individual Type 1 diabetic patients are shown in Figure 2. The prevalence of "relative hypertension" ( $>90$ th centile for age and sex) amongst the female diabetic patients was $9 / 66(14 \%)$; this does not differ significantly from that amongst female siblings $12 / 95(13 \%)$. However, amongst the males there is a significant preponderance of diabetic patients with mean BP exceeding the 90th centile; 18/97 (19\%) compared with $12 / 137(9 \%)$ of siblings ( $p=0.05$, Fisher's exact test). This excess is not totally explicable by the increase in DBP alone, which would increase mean BP by about $1.5 \mathrm{mmHg}$.

Characteristics of subjects with "relative hypertension". The frequency of various factors present in the diabetic and sibling groups with "relative hypertension" are shown in Table 3.

Of the 27 diabetic patients ( 18 male, 9 female) with mean BP exceeding the 90th centile for their age and sex, $5(19 \%)$ had urinary albumin concentrations over $30 \mathrm{mg} / 1$ on random urine samples (Table 3 ). Two of these completed 24-h urine collections which confirmed albumin excretion rates $>12 \mu \mathrm{g} / \mathrm{min}$; a further $3 \mathrm{sub}-$ jects had random albumin concentrations $<30 \mathrm{mg} / \mathrm{l}$ but values $>12 \mu \mathrm{g} / \mathrm{min}$ on 24 -h collections. All except one of the 8 with increased albumin concentration or excretion rate had been diabetic for over 8 years; only one had recognised clinical nephropathy (Albustixpositive proteinuria and proliferative retinopathy) (Table 4).
For these 27 with "relative hypertension", 18 of 46 $(39 \%)$ available parents had BP (phases I/V) $>140 / 90$ (thus having borderline or definite hypertension by WHO criteria, which use phase V DBP) compared with

Table 3. Characteristics of subjects with mean blood pressure above 90 th centile for age and sex

\begin{tabular}{|c|c|c|c|c|}
\hline & \multicolumn{2}{|c|}{ Diabetic patients } & \multicolumn{2}{|l|}{ Siblings } \\
\hline & Number & Percentage & Number & Percentage \\
\hline Possible subjects & 163 & & 232 & \\
\hline $\begin{array}{l}\text { Number with BP } \\
>90 \text { th centile }\end{array}$ & 27 & 17 & 25 & 11 \\
\hline $\begin{array}{l}\text { Male: female ratio } \\
\text { (\%age male) }\end{array}$ & $18: 9$ & 67 & $12: 13$ & 48 \\
\hline $\begin{array}{l}\text { Parents with BP } \\
>140 / 90 \text { or on } \\
\text { treatment }^{\mathrm{a}}\end{array}$ & $21 / 44$ & 48 & $30 / 49$ & 59 \\
\hline $\begin{array}{l}\text { Number with body } \\
\text { mass index } \\
>26 \mathrm{~kg} / \mathrm{m}^{2}\end{array}$ & $2 / 27$ & 7 & $7 / 25$ & 28 \\
\hline $\begin{array}{l}\text { Number with } \\
\text { increased albumin } \\
\text { excretion }^{\mathrm{b}}\end{array}$ & $8 / 27$ & 29 & - & - \\
\hline $\begin{array}{l}\text { Number of oral } \\
\text { contraceptive users }\end{array}$ & $3 / 9$ & 33 & $4 / 13$ & 31 \\
\hline
\end{tabular}

${ }^{a} \mathrm{BP}$ recorded as detailed in text or receiving antihypertensive therapy at time. ${ }^{b}$ Those with $24-\mathrm{h}$ albumin excretion $>12 \mu \mathrm{g} / \mathrm{min}$ or random albumin concentration $>30 \mathrm{mg} / 1$. ${ }^{c}$ Expressed as proportion of females receiving oral contraceptives.

None of the differences between the groups are significant (Fisher's exact test) 
24 of 49 parents (49\%) in the comparable sibling group (Table $3 ; p=\mathrm{NS}$ ). Both these were significantly higher than in the parents of normotensive children (54 of 217 parents, $25 \% ; p<0.05$ versus diabetic patients, $p<$ 0.0001 versus siblings).

Other individual data on the subjects with "relative hypertension", such as body mass index, insulin dosage, oral contraceptive use and blood glucose at time of BP measurement are shown in Table 4. Only one subject was hypoglycaemic (blood glucose $<2.2 \mathrm{mmol} / \mathrm{l}$ ), though many had high random blood glucose levels.

\section{Discussion}

We have demonstrated a small but significant increase $(2.7-2.8 \mathrm{mmHg})$ in overall phase IV DBP of our young male Type 1 diabetic population as compared with their non-diabetic siblings, with the difference statistically demonstrable in the 16-20 year age band. A trend of borderline significance is seen in phase V DBP in males, but no significant difference of DBP is shown in females. Systolic pressures were, however, similar in both sexes throughout the age range.

The population studied was community-based rather than hospital-based. We accept that siblings do not represent a random control population, but the use of this group does allow other factors which may influence BP such as social class, dietary habits, genetic and familial environmental factors, geographical region and medical familiarity to be accounted for. Possible errors in measurement have been minimised by the use of a single non-uniformed observer, a random zero sphygmomanometer, the use of the mean of three readings (each to $2 \mathrm{mmHg}$ ) and by recording BP in the patients' homes. For these reasons, and because of the similar SBPs, we feel that it is difficult to attribute these findings to any systematic error. Statistically, the difference (altered mean but similar SD) appears to be due to a shift of the whole population rather than to a small population with marked increases in DBP; this implies that the cause may be general to all Type 1 diabetic patients rather than limited to a few.

Our findings differ from those of previous studies. Thus, Moss [3] reported higher SBP in diabetic boys, though no formal statistical analysis was employed. Kaas-Ibsen et al. [4] found lower DBP among diabetic girls, but the validity of this data is limited by the use of multiple observers. Cruickshanks et al. [6], with a single observer, found higher SBP and DBP $(\triangle \mathrm{BP}=$ 4-6 $\mathrm{mmHg}$ ) in 149 diabetic adolescents; however their cases were older than their limited number of 45 control subjects. Their adolescents had also been diabetic for longer than our group of comparable age.

Possible explanations for the higher DBP include a small increase in peripheral vascular resistance [21] and/or increased plasma viscosity, possibly secondary to hyperglycaemia. Others have shown that improving diabetic control reduces BP slightly [22-23], though this effect was greater on SBP [23]. Alternative possibilities include transient hypoglycaemia causing hypertension by catecholamine release, but hypoglycaemia was only present in one patient (Table 4) and could not affect the data for the whole population. Another explanation might be decreased physical exercise among the diabetic group.

Whilst small in the terms of the individual affected, such a shift in the population distribution may be of some importance [24]. Actuarial data for the general population suggests that such an increase, present from childhood onwards, might be associated with slight loss of life expectancy from cardiovascular and cerebrovascular events; there is no reason to think that diabetic patients are exempt from such events [25]. However it seems unlikely that such a small difference in BP could explain the considerable excess cardiovascular morbidity in diabetic patients. It is, though, clearly possible that older subjects with longer duration of diabetes might show greater differences [1].

This increased risk of excess cardiovascular morbidity is additional to the definite relationship that increased BP has with 'incipient' or established diabetic nephropathy, itself a major cause of death in Type 1 diabetes.

We have also shown a small excess of male diabetic patients with mean BP above the 90th centile, though they alone cannot account for the shift in the population mean for DBP. We have used the term "relative hypertension" to define such a group of both diabetic patients and non-diabetic siblings with inappropriately high BP for their age, although only 15 of the 27 diabetic patients fulfill the World Health Organisation criteria for even "borderline" hypertension and only 7 are "hypertensive". These standards are clearly inappropriate to the younger part of this age range [26, 27]. On this basis we have identified a group of relatively hypertensive diabetic patients and non-diabetic siblings in whom the presence of some possible aetiological factors (e.g. early nephropathy, obesity and parental hypertension) was examined further.

'Microalbuminuria' is now established as a marker for early nephropathy. While the use of random urine samples to estimate microalbuminuria is much less accurate than overnight timed samples, it does have moderate reliability, and permits sampling of a much higher proportion of the population than overnight or $24 \mathrm{~h}$ urine samples [28]; in addition $81 \%$ of these subjects did collect a $24 \mathrm{~h}$ urine sample. It thus seems unlikely (Table 4) that the majority of these subjects have even minimal elevation of albumin excretion.

Three recent hospital-based studies have demonstrated an association between small increases in BP and microalbuminuria in young adult diabetic patients [9-11]. Although these reports use slightly different criteria and methodology, the average BP levels found are very similar; $136 / 87,131 / 85$ and $138 / 89 \mathrm{mmHg}$ for 
Table 4. Individual details of Type 1 diabetic patients with mean blood pressures above 90 th centile for age and sex

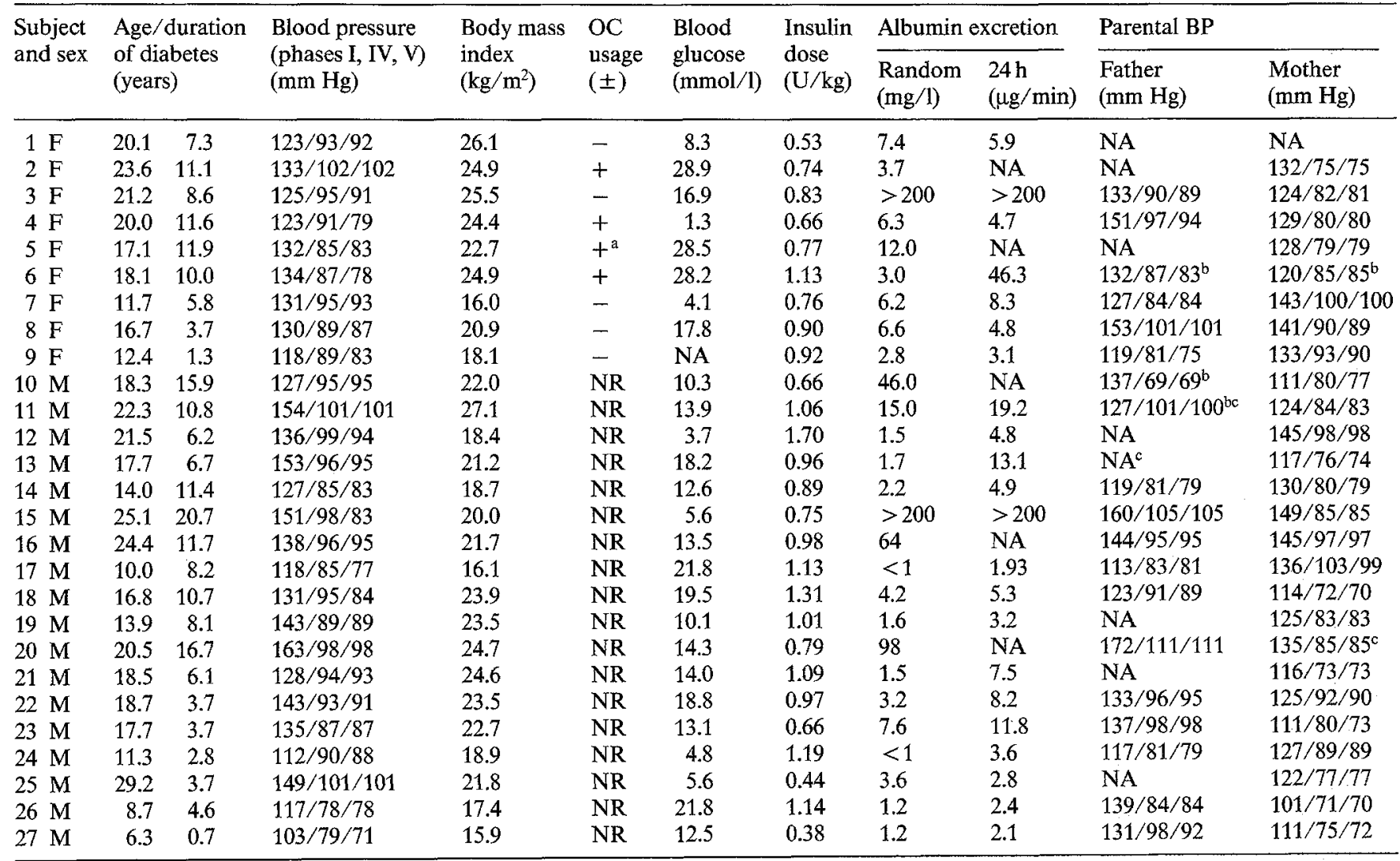

$\mathrm{OC}=$ Oral contraceptive (combined oestrogen/progestogen); normal range for 24 -h albumin excretion $<12 \mu \mathrm{g} / \mathrm{min}$. NA $=$ not available; $\mathrm{NR}=$ not relevant. ${ }^{\mathrm{a}}=$ on progesterone-only contraceptive; ${ }^{b}=$ diabetic parent ${ }^{c}=$ parent receiving oral anti-hypertensive therapy

those with microalbuminuria, and 119/79, 124/79 and $124 / 80 \mathrm{mmHg}$ for those with normal albumin excretion rates. It is noteworthy that these increases are again predominantly in SBP, whereas the change we found was in DBP with an altered population mean. There is conflicting data on whether hypertension itself is a risk factor for the development of nephropathy; the consensus of opinion would seem to be that it is not a primary factor [29] but probably accelerates its development once present [30].

While two groups have suggested that aggressive treatment of hypertension in Type 1 diabetic patients with nephropathy may reduce the rate of deterioration of renal function [31,32], it is not known whether such treatment at the lower BP of "relative hypertension" will prevent or retard the development of nephropathy, retinopathy or cardiovascular complications.

In most other studies, the familial contribution to blood pressure has been assessed simply on a history of hypertension or hypertension-related disease. We sought to minimise the inaccuracy in parental data by recording their BP ourselves under identical conditions to those used for the children; we have also shown presumed parenthood to be compatible with HLA tissue typing results.

The possible role of coincident essential hypertension in diabetes is more difficult to assess because of the lack of any specific marker, but the increased prevalence of parental hypertension in this group would tend to support the view that the majority of these diabetic patients with "relative hypertension" may in fact have essential hypertension [33].

The finding that long-term (40 year) survivors with diabetes have lower DBP than control subjects [34], together with the familial inheritance of BP that we have shown, might provide an explanation for the suggested association of length of survival of diabetic patients and parental longevity.

In conclusion, we have shown a small (2.7-2.8 $\mathrm{mmHg}$ ) increase in diastolic blood pressure among young male Type 1 diabetic patients from childhood onwards, but no difference in systolic blood pressure in either sex. There is also evidence of a small excess of male diabetic patients with relatively high mean blood pressure. The results, however, appear to exclude a major systematic increase in blood pressure in young patients with Type 1 diabetes of relatively short duration, and cannot of itself explain more than a small part of their subsequent cardiovascular mortality and morbidity. The mechanism of this selective increase in diastolic pressure is not clear, but does not appear to be explicable by the presence of even early nephropathy. It may, 
however, throw light on the pathophysiology of blood pressure control and vascular disease in Type 1 diabetes.

Acknowledgements. Dr. Tarn was supported by the Medical Research Council. We are grateful for the encouragement and advice of Dr. J. Lister, Dr. E. A. M. Gale and Prof. G. A. Rose, and for the continued cooperation of the families.

\section{References}

1. Christlieb AR, Warram JH, Krolewski AS, Busick EJ, Ganda OM, Asmal AC, Soeldner JS, Bradley RF (1981) Hypertension: The major risk factor in juvenile onset insulin-dependent diabetes. Diabetes 30: 90-96

2. Knowler WC, Bennett PH, Ballintine EJ (1980) Increased incidence of retinopathy in diabetics with elevated blood pressure. $\mathrm{N}$ Eng1 J Med 302: 645-650

3. Moss AJ (1962) Blood pressure in children with diabetes mellitus. Pediatrics 1962; 30: 932-936

4. Kaas Ibsen K, Rotne H, Hougaard P(1983) Blood pressure in children with diabetes mellitus. Acta Paediatr Scand 72: 191-196

5. Young RJ, MacIntyre CCA, Prescott RJ, Viberti GC, Clarke BF (1984) Subclinical renal microangiopathy and raised diastolic blood pressure in young diabetics. Diabetic Medicine 1: 137A (Abstract)

6. Cruickshanks KJ, Orchard TJ, Becker DJ (1985) The cardiovascular risk profile of adolescents with insulin-dependent diabetes mellitus. Diabetes Care 8: 118-124

7. Watkins PJ, Blainey JD, Brewer DB, Fitzgerald MG, Malins JM, O'Sullivan DJ, Pinto JA (1972) The natural history of diabetic renal disease. Q J Med 41: 437-456

8. Mann GV, Gardner C, Root HF (1949) Clinical manifestations of intracapillary glomerulosclerosis in diabetes mellitus. Am J Med $7: 3-17$

9. Wiseman M, Viberti G, Mackintosh D, Jarrett RJ, Keen H (1984) Glycaemia, arterial pressure and microalbuminuria in Type 1 (insulin-dependent) diabetes mellitus. Diabetologia 26: 401-405

10. Mathiesen ER, Oxenboll B, Johansen $K$, Svendsen PAa, Deckert $T$ (1984) Incipient nephropathy in Type 1 (insulin-dependent) diabetes. Diabetologia 26: 406-410

11. Mogensen CE, Christensen CK (1984) Predicting diabetic nephropathy in insulin-dependent patients. N Engl J Med 311: 89-93

12. Lestradet H, Papoz L, Hellouin de Menibus CL, Levavasseur E, Besse J, Billaud L, Battistelli F, Tric Ph, Lestradet F (1981) Long term study of mortality and vascular complications in juvenile onset (Type 1) diabetes. Diabetes 30: 175-179

13. Gorsuch AN, Spencer KM, Lister J, Wolf E, Bottazzo GF, Cudworth AG (1982) Can future Type 1 diabetes be predicted? A study in families of affected children. Diabetes 31: 862-866

14. Tarn AC, Drury PL, Schwarz G, Bottazzo GF, Gale EAM (1984) Diabetes mellitus in offspring of diabetic mothers or fathers. $N$ Engl J Med 311: 1185 (Letter)

15. Mancia G, Ferrari A, Gregorini L, Grassi G, Pomidossi G, Bertinieri G, Parati G, Zanchetti A (1983) Effects of blood pressure measurement by the doctor on patient's blood pressure and heart rate. Lancet 2: 695-698

16. Kirkendall WM, Burton AC, Epstein FH, Freib ED (1967) Recommendations for human blood pressure determination by sphygmomanometer. Circulation 36: 980-988
17. Webster J, Newnham D, Petrie JC, Lovell HG (1984) Influence of arm position on measurement of blood pressure. $\mathrm{Br}$ Med $\mathrm{J} 288$ : 1574-1575

18. Keen $\mathrm{H}$, Chlouverakis $\mathrm{C}$ (1963) An immunoassay method for urinary albumin at low concentrations. Lancet 2:913-916

19. Task Force on blood pressure control in children (1977) Pediatrics 59 (Suppl): 797-820

20. Hamilton M, Pickering GW, Roberts JAF, Sowry GSC (1954) The aetiology of essential hypertension. 1. The arterial pressure in the general population. Clin Sci 13:11-35

21. Faris I, Agerskov K, Hendriksen O, Lassen NA, Parving $\mathrm{HH}$ (1982) Decreased distensibility of a passive vascular bed in diabetes mellitus: an indicator of microangiopathy. Diabetologia 23: 411-414

22. O'Hare JA, Ferriss JB, Twomey BM, Gonggrijp H, O'Sullivan DJ (1982) Changes in blood pressure, body fluids, circulating angiotensin II and aldosterone with improved diabetic control. Clin Sci $63: 415 \mathrm{~s}-418 \mathrm{~s}$

23. Mathiesen ER, Hilsted J, Feldt-Rasmussen B, Bonde-Petersen F, Christensen NJ, Parving H-H (1985) The effect of metabolic control on hemodynamics in short-term insulin-dependent diabetic patients. Diabetes 34: 1301-1305

24. Rose G (1981) Strategy of prevention: lessons from cardiovascular disease. Br Med J 282: 1847-1851

25. Society of Actuaries (1980) Blood Pressure Study, 1979. Society of Actuaries, Chicago

26. World Health Organisation (1979) Arterial Hypertension. Report of a WHO Expert Committee on hypertension. WHO Technical Report Series No.628, Geneva, World Health Organisation

27. Drury PL, Tarn AC (1985) Are the W.H.O. criteria for hypertension appropriate in young insulin-dependent diabetics? Diabetic Medicine 2, 79-82

28. Gatling W, Knight C, Hill PD (1985) Screening for early diabetic nephropathy: which sample to detect microalbuminuria? Diabetic Medicine 2: 451-455

29. Deckert T, Poulsen JE (1981) Diabetic nephropathy: fault or destiny? Diabetologia 21: 178-183

30. Hasslacher C, Stech W, Wahl P (1985) Blood pressure and metabolic control as risk factors for nephropathy in Type 1 (insulin-dependent) diabetes. Diabetologia 28: 6-11

31. Parving HH, Andersen AR, Smidt UM, Svendsen PAa (1983) Early aggressive antihypertensive treatment reduces the rate of decline in kidney function in diabetic nephropathy. Lancet 1: 1175-1178

32. Mogensen CE (1982) Long-term antihypertensive treatment inhibiting progression of diabetic nephropathy. Br Med J 285: 685-688

33. Miall WE, Oldham PD (1963) The hereditary factor in arterial blood pressure. Br Med J 1:75-80

34. Borch-Johnsen K, Nissen RN, Nerup J (1985) Blood pressure after 40 years of insulin-dependent diabetes. Diabetic Nephropathy 4: $11-12$

Received: 6 May 1985

and in revised form: 21 February 1986

\author{
Dr. Paul Drury \\ Departments of Diabetes \\ King's College Hospital \\ Denmark Hill \\ London SE5 9RS \\ UK
}

